\title{
A Link between Oil Price and Stock Market Index: The Case of Three Countries
}

\author{
Maya Katenova ${ }^{1}$ \\ Zhanat Syzdykov² \\ ${ }^{1,2}$ Kimep University Kazakhstan, Kazakhstan \\ Email:mavak@kimep.k \\ ${ }^{2}$ Email: $\approx$ sy $\approx$ dykov@kimep.k $\approx$
}

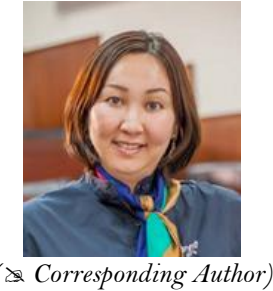

\begin{abstract}
This study empirically explores the causal relationship between the stock market development and oil price in Russia, UK and Kazakhstan. With this aim, the data between 2000 and 2017 was used. This data was obtained from Bloomberg. The data includes Index KASE, RTS Index, FTSE Index and oil price. In order to find out the dependence between oil price and indexes of United Kingdom, Russian Federation and Kazakhstan (FTSE 100 index, RTS index and index KASE respectively) it was necessary to collect the data first of all. For the analysis it was decided to choose, as variables, the prices and trade volumes of chosen instruments. As it was mentioned previously, I looked through the 17-year period starting from January $1^{\text {st }}$, 2000 lasting January $1^{\text {st }}, 2018$. Monthly data was retrieved from Bloomberg. The purpose of the empirical analysis is to determine what kind of relationship, if any, exists between oil price and such stock indices as KASE Index, RTS Index and FTSE Index. This study investigates the interaction between the oil price and three indices. Quite an interesting fact is that there are no any significant relationships between oil price and indexes studied. Among all indices studied, Index KASE is the most dependent on oil prices. The least dependent index is FTSE index. It is important to understand that every country has its own research environment and special features, which also could be researched independently. Taking into consideration the importance of oil export earnings to the growth profile of the Kazakhstani economy, higher oil export revenues would result in the growth of Index KASE. Majority of companies listed in Kazakhstani index are export oriented. Thus, the study can serve as a promising avenue for further research. For example, for Kazakhstan, some new research indicators can be added, such as weight of export and import.
\end{abstract}

Keywords: Stock market index, Oil price, Russia, UK, Kazakhstan.

JEL Classification: Stock market, Oil price, FTSE, RTS, KASE index.

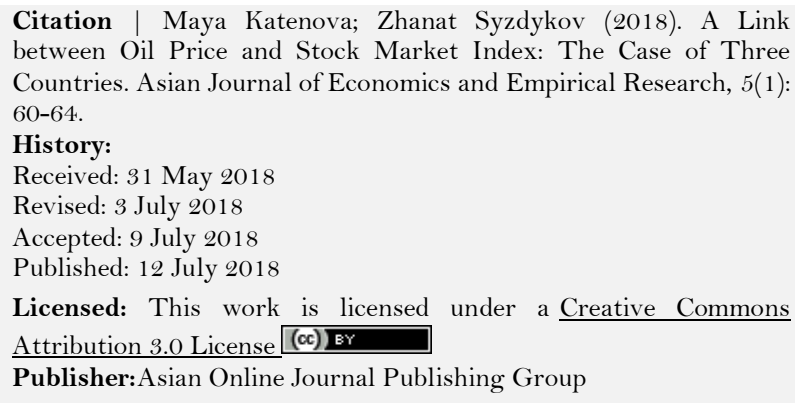

Citation | Maya Katenova; Zhanat Syzdykov (2018). A Link between Oil Price and Stock Market Index: The Case of Three Countries. Asian Journal of Economics and Empirical Research, 5(1): 60-64.

History:

Received: 31 May 2018

Revised: 3 July 2018

Accepted: 9 July 2018

Published: 12 July 2018

Licensed: This work is licensed under a Creative Commons

Attribution 3.0 License (oc)

Publisher:Asian Online Journal Publishing Group

Contribution/Acknowledgement: Both authors contributed to the conception and design of the study.

Funding: This study received no specific financial support.

Competing Interests: The authors declare that they have no conflict of interests.

Transparency: The authors confirm that the manuscript is an honest, accurate, and transparent account of the study was reported; that no vital features of the study have been omitted; and that any discrepancies from the study as planned have been explained.

Ethical: This study follows all ethical practices during writing.

\section{Contents}

1. Introduction 61

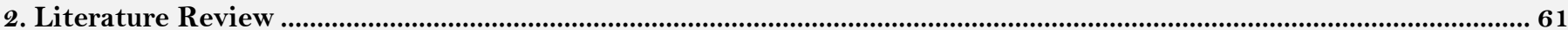

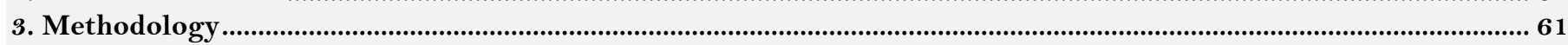

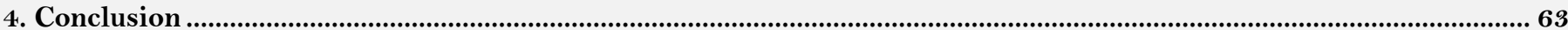

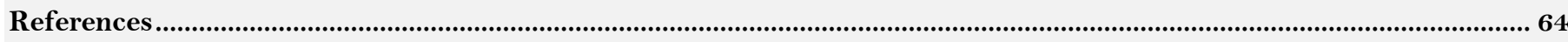

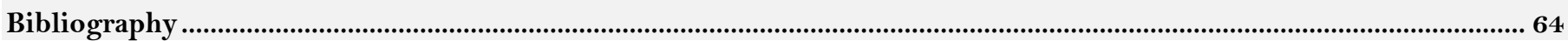




\section{Introduction}

The main aim of the economic development of the country is to increase overall wealth, become stronger and achieve to be a respected player in the world arena. One of the ways to improve efficiency is to develop strong financial market. This research paper is going to look for the links between oil price and stock market index: in United Kingdom, Russian Federation and Kazakhstan.

Due to the high volatility of oil prices in recent years, the economy of some oil-producing countries has been on the verge of a crisis. In the list of such countries were Russian Federation and Kazakhstan, who had faced the devaluation of national currencies right after the oil price fall. Thus it would be interesting to look through the influence of such fluctuations on the economy of the countries. So, second objective which is going to be observed in this paper is the dependence of stock market index on oil price.

It is expected that fluctuations in the price of oil affect the economy of developing and developed countries on different scales. This is happening due to the different industrialization levels. Every country which has a financial market typically has its own stock market index, which consists from stocks of local companies from the most developed and perspective industries. Thus, stock market index could be considered as a reflection of the economic condition of the country at a certain period of time. The indices of the UK, Russian Federation and Kazakhstan include companies from 40,14 and 5 industries respectively. Due to this fact, third research question of this paper is going to observe the impact of the industrialization on the developing and developed countries.

Countries chosen for the research have their own indices, which serve as a measurement of stock market development at a certain point of the time: "KASE Index" for Kazakhstan, "FTSE 100" for UK and "RTS" for Russian Federation. The youngest among all three is KASE Index, which emerged in the year 2000, thus this year is going to be considered as the starting point of the research. In order to find out the answers for these questions, historical monthly data (from year 2000 until 2017) of the stock market indexes of London Stock Exchange (Index FTSE 100), Kazakhstani Stock Exchange (Index KASE) and Russian Trading System (Index RTS) is going to be observed. Indexes prices, trade volume and returns will be compared with the data of Generic oil in order to find out a dependence of expected market condition (historical) and exact market condition (actual). Expected results of this thesis are going to be useful for the further research, especially if the answers for the research questions would be positive.

\section{Literature Review}

Many experts all over the world recognize the importance of oil price on the economy. Different studies had examined various aspects of oil price and macroeconomic relationship for different countries. According to Brown and Yicel (2002) oil price definitely influence macroeconomic variables, such as, for instance, output, prices, GDP and unemployment.

According to Huang et al. (1996) oil stock price can be linked with the stock market with the usage of equity pricing model. At any point of time, price of equity can be equated to the discounted PV of the future net earnings. So, oil price shocks could be immediately reflected in the prices, which means that increase in oil price can reduce future net earnings and hence stock price is expected to be negatively correlated with the oil price shocks.

Analogically, most of the published literature on the topic documented a negative relationship between oil price and stock market activities Chen (2010); Masih et al. (2011); Basher et al. (2012). However, there are articles, which still argue with this position.

Arouri et al. (2011) explored the linear and nonlinear long-term relationships between oil prices and stock prices. Authors wanted to define, whether changes in oil price equally affect changes in a stock prices. The investigation was made on the basis of the post-1997 Asian financial crisis: from January 01, 1998, to November 13, 2008. Arouri et al. (2011) made a set of tests, which showed the existence of significant asymmetric cointegrating relationships between oil prices and several European stocks.

Abhyankar et al. (2013) presented the information on the link between stock market and oil price on the basis of Japan. Due to the fact that Japan in not a country which produces oil, and forced to import it at a price which is set by the seller, an increase in oil price should theoretically have a negative consequence on the economy of Japan. However, authors concluded, that "oil price shocks that arise from changes in aggregate global demand are positively correlated to returns on the Japanese stock market". Which means, that an increase in oil price sufficiently increase the performance of Japanese stock market.

\section{Methodology}

In order to find out the dependence between oil price and indexes of United Kingdom, Russian Federation and Kazakhstan (FTSE 100 index, RTS index and index KASE respectively) it was necessary to collect the data first of all. For the analysis it was decided to choose, as variables, the prices and trade volumes of chosen instruments. As it was mentioned previously, I looked through the 17-year period starting from January $1^{\text {st }}$, 2000 lasting January $1^{\text {st }}$, 2018. Monthly data was retrieved from Bloomberg.

Two standard procedures of unit root test namely the Augmented Dickey Fuller (ADF) and Phillips-Perron (PP) tests are employed. $\Delta y_{t}=\alpha_{0}+\alpha_{1} y_{t-1}+\alpha_{2}$ trend $+\sum \beta_{j} \Delta y_{t-j}+\mu_{t}$

The Augmented Dickey Fuller Test (ADF) is one of the most common unit roots tests for stationarity. The null hypothesis for this test is that there is a unit root, which means that the data is non stationary. Alternative hypothesis states that the data is non- stationary.

Finally, the Least squares method (LS) is employed. According to Charnes et al. (1976) the method of least squares is a standard approach in regression analysis to approximate the solution of over determined systems. "Least squares" means that the overall solution minimizes the sum of the squares of the residuals made in the results of every single equation.

This study empirically explores the causal relationship between the stock market development and oil price in Russia, UK and Kazakhstan. With this aim, the data between 2000 and 2017 was used. This data was obtained from Bloomberg. 
The data includes Index KASE, RTS Index, FTSE Index and oil price.

Table-1. Unit Root Test

\begin{tabular}{|c|c|c|c|c|}
\hline Unit root and stationarity & $\operatorname{ADF}(1 \%)$ & ADF (5\%) & PP (1\%) & $\mathrm{PP}(5 \%)$ \\
\hline Critical values & -3.48 & -2.88 & -3.48 & -2.88 \\
\hline KASE Index & 1.29 & & 1.28 & \\
\hline FTSE Index & -1.19 & & -1.22 & \\
\hline RTS Index & -1.55 & & 1.57 & \\
\hline \multirow[t]{2}{*}{ Oil price } & -1.99 & & -1.94 & \\
\hline & 1.45 & & 1.48 & \\
\hline
\end{tabular}

Source: Unit root test from e-views

As it was mentioned previously, first of all, it was necessary to make the data appropriate for further research. It can be observed from the Table 1, that according to the ADF and PP models we fail to reject the null hypothesis, which states that the data has unit root and is stationary, because it lies between the critical values $-3,48$ and $-2,88$ for both tests with $1 \%$ and $5 \%$ probabilities respectively.

Table-2. Unit Root Test

\begin{tabular}{l|l|l|l|l}
\hline Unit root test & ADF (1\%) & ADF (5\%) & PP (1\%) & PP (5\%) \\
\hline Critical values & -3.48 & -2.88 & $-3,48$ & $-2,88$ \\
\hline KASE Index & -6.87 & -6.91 & \\
\hline FTSE Index & -9.96 & -9.89 & \\
\hline RTS Index & -11.35 & -11.42 & 10.51 \\
\hline Oil price & 10.45 & 11.28 & \\
\hline \multicolumn{7}{l}{} \\
Source: Unit root test from e-views
\end{tabular}

Table 2 reflects the results after we transform all-time series into natural logarithm values. As a result, according to the ADF and PP models we can reject the null hypothesis, and state that the data doesn't have unit root and is stationary, because it lies above the critical values -3, 48 and -2, 88 for both tests with $1 \%$ and $5 \%$ probabilities respectively.

That means that the data become appropriate for further research, and with the usage of this results I can look through the correlation between KASE Index, FTSE Index, RTS Index and oil price. The results of the test could be observed in the Table 4 . There are 204 monthly observations, which cover a ten-year period of time starting in January 2000 and finishing in December 2017. First of all, oil price was employed. Such indices as KASE Index, RTS Index and FTSE Index were employed in the study.

The purpose of the empirical analysis is to determine what kind of relationship, if any, exists between oil price and such stock indices as KASE Index, RTS Index and FTSE Index.

The least square method (LS) was applied to check relationship between dependent variables Index KASE $=8701191134.38+1957110.94384 *$ Oil Price

Obtained coefficient has an expected "plus" sign, which implies positive influence on Assets. The regression results show that change of oil price by one unit will lead to increase of the KASE Index value by 1957110.94 units.

Table-3. Index KASE and Oil price

Dependent Variable: Index KASE

Method: Least Squares

Date: 01/25/2018 Time: 10:15

Sample: 2000M01 2017M12

Included observations: 204

\begin{tabular}{l|l|l|l|l}
\hline & Coefficient & Std. Error & t-Statistic & Prob. \\
\hline Oil price & 1957111. & 602827.6 & 3.246551 & 0.0018 \\
\hline C & $8.70 \mathrm{E}+09$ & $7.10 \mathrm{E}+08$ & 12.26016 & 0.0000 \\
\hline R-squared & 0.130868 & Mean dependent var & $1.08 \mathrm{E}+10$ \\
\hline Adjusted R-squared & 0.118452 & S.D. dependent var & $2.54 \mathrm{E}+09$ \\
\hline S.E. of regression & $2.38 \mathrm{E}+09$ & Akaike info criterion & 46.05018 \\
\hline Sum squared resid & $3.98 \mathrm{E}+20$ & Schwarz criterion & 46.11342 \\
\hline Log likelihood & -1655.806 & Hannan-Quinn criter. & 46.07536 \\
\hline F-statistic & 10.54010 & Durbin-Watson stat & 0.089219 \\
\hline Prob (F-statistic) & 0.000194 & & \\
\hline Source: Ordinary Least Squares from e-views & &
\end{tabular}

The regression above has the right functional form that confirms F-statistic coefficient (10.54010) with small p-value (0.000194). At the same time, R-squared, this measures the proportion of the variation in the dependent variable - Index KASE accounted for by the explanatory variable oil price, equals to 0.130868. It means that regression model describes insignificantly than $13 \%$ of the pattern in the oil price. In other words, $1 \%$ increase in oil price leads to $13 \%$ increase in Index KASE. The regression also has positive autocorrelation in residuals according to Durbin-Watson statistic (0.089219). Residuals of the regression have no normal distribution with Kurtosis 3.0 and Skewness -1.11. Although the obtained coefficient is statistically significant in keeping with large t-statistic 3.246551 and small p-value, it cannot be reliable because of autocorrelation in residuals.

The next step in the study was to analyze the relationship between oil price and RTS Index. 
Table-4. RTS Index and oil price

Dependent Variable: RTS Index

Method: Least Squares

Date: 01/25/18 Time: 10:18

Sample: 2000Mo1 2017M12

Included observations: 204

\begin{tabular}{l|l|l|l|l}
\hline & Coefficient & Std. Error & t-Statistic & Prob. \\
\hline Oil price & 3628495. & 492928.0 & 7.361105 & 0.0000 \\
\hline $\mathrm{C}$ & 79023539 & $1.48 \mathrm{E}+09$ & 0.053532 & 0.9575 \\
\hline R-squared & 0.107654 & Mean dependent var & $1.08 \mathrm{E}+10$ \\
\hline Adjusted R-squared & 0.1028276 & S.D. dependent var & $2.54 \mathrm{E}+09$ \\
\hline S.E. of regression & $1.92 \mathrm{E}+09$ & Akaike info criterion & 45.61715 \\
\hline Sum squared resid & $2.58 \mathrm{E}+20$ & \multicolumn{2}{|l}{ Schwarz criterion } & 45.68040 \\
\hline Log likelihood & -1640.218 & Hannan-Quinn criter. & 45.64233 \\
\hline F-statistic & 54.18587 & Durbin-Watson stat & 0.880701 \\
\hline Prob(F-statistic) & 0.000000 & &
\end{tabular}

The results of the second regression are fully consistent with the results of the first one, $1 \%$ increase in oil price leads to $10,7 \%$ increase in RTS index. The regression has right functional form with large F-statistic - 54.1859 and small p-value (0.000000). The coefficient of determination $\mathrm{R}^{2}$ equals 10.7654\%. The value of this coefficient characterizes the fraction of variance in the dependent variable RTS index that can be explained by regression, i.e. of the independent variable, which is oil price. Accordingly, the value of $1-\mathrm{R}^{2}$ characterizes the proportion of variance of Assets, caused by the influence of all the others taken into account in the econometric model. The regression also has got positive autocorrelation of residuals that confirms small Durbin - Watson statistics (0.880701). Therefore, we cannot fully rely on the results of the regression.

Table-5. FTSE Index and Oil price

Dependent Variable: FTSE Index

Method: Least Squares

Date: 01/25/18 Time: 10:21

Sample: 2000M01 2017M12

Included observations: 204

\begin{tabular}{l|l|l|l|l}
\hline & Coefficient & Std. Error & t-Statistic & Prob. \\
\hline GDP & -893447.6 & 185428.0 & -4.818299 & 0.0000 \\
\hline C & $1.74 \mathrm{E}+09$ & $2.18 \mathrm{E}+08$ & 7.984789 & 0.0000 \\
\hline R-squared & 0.049056 & Mean dependent var & $7.77 \mathrm{E}+08$ \\
\hline Adjusted R-squared & 0.038328 & S.D. dependent var & $8.41 \mathrm{E}+08$ \\
\hline S.E. of regression & $7.34 \mathrm{E}+08$ & Akaike info criterion & 43.69225 \\
\hline Sum squared resid & $3.77 \mathrm{E}+19$ & \multicolumn{2}{l}{ Schwarz criterion } & 43.75549 \\
\hline Log likelihood & -1570.921 & Hannan-Quinn criter. & 43.71743 \\
\hline F-statistic & 23.21601 & Durbin-Watson stat & 0.278177 \\
\hline Prob(F-statistic) & 0.000008 & & \\
\hline \multicolumn{2}{l}{ source: Ordinary Least Squares from e-views }
\end{tabular}

The same conclusion can be done by looking at the last regression, where the Durbin - Watson statistic will be considered. This coefficient clearly shows the presence of positive autocorrelation of the disturbance terms.

The last regression model reveals the relationship between Oil price and FTSE Index. In this case, all coefficients show full statistical insignificance of the model. Coefficient of determinations $\mathrm{R}^{2}$ is only 0.049056 which means that the regression describes only four percent of the phenomenon. $1 \%$ increase on oil price leads to $4,9 \%$ increase in FTSE 100. F-statistic confirmed wrong functional form of the regression model and Durbin Watson statistic showed the presence of positive autocorrelation among disturbance terms. FTSE index has lower dependence in comparison with Index KASE and RTS Index.

\section{Conclusion}

This study investigates the interaction between the oil price and three indices. Quite an interesting fact is that there are no any significant relationships between oil price and indexes studied. Among all indices studied, Index KASE is the most dependent on oil prices. The least dependent index is FTSE index.

It is important to understand that every country has its own research environment and special features, which also could be researched independently. Taking into consideration the importance of oil export earnings to the growth profile of the Kazakhstani economy, higher oil export revenues would result in the growth of Index KASE. Majority of companies listed in Kazakhstani index are export oriented. Thus, the study can serve as a promising avenue for further research. For example, for Kazakhstan, some new research indicators can be added, such as weight of export and import. Moreover, after the devaluation of national currency in 2015, National Bank of Kazakhstan applied free floating exchange rate, which allows the legislator to control some economic components. For example, National Bank of Kazakhstan can artificially keep foreign exchange rate of national currency at a preditermined rate by trading tenge. This fact also might affect the results of my research due to the fact that such interventions also help to keep the preditermined inflation rate.

When it comes to the Russian Federation, the results of my research are the most unexpected. Oil and gas companies compose nearly half of the RTS stock index, however according to the research, $1 \%$ change in oil price affect only 10,7\% change in the RTS index. It can be considered, that there are also some environmental issues in the case. For example, further it can be checked how the anti-russian economic sanctions influences on the stock market and oil and gas industry. 
When it comes to the FTSE 100, it is still can be considered as one of the most stable and reliable economic indicator. However, it is still unclear in terms of FTSE index and some internal and external shocks. Monetary stability does not necessarily lead to financial market stability and the study did not explore the reason of British financial market stability.

Not only new indicators can be added, such as balance of trade data, export, import, inflation or GDP, but also some new oil extracting countries could be compared, such as Mexico, Brazil, Iraq, Iran and etc. Moreover, as it can be observed from the literature review, there is a lot of different tests, methods and analysis's, (for example VAR or GARCH) which also can be used in order to look though the impact of oil price and economy of the countries. So this paper may serve as a promising avenue for the further research.

\section{References}

Abhyankar, A., B. Xu and J. Wang, 2013. Oil price shocks and the stock market: Evidence from Japan. Energy Journal, 34(2): 199-222. View at Google Scholar

Arouri, M.E.H., P. Foulquier and J. Fouquau, 2011. Oil prices and stock markets in Europe: A sector perspective. Recherches Économiques de Louvain/Louvain Economic Review, 77(1): 5-30. View at Google Scholar View at Publisher

Basher, S.A., A.A. Haug and P. Sadorsky, 2012. Oil prices, exchange rates and emerging stock markets. Energy Economics, 34( 1): 227-240. View at Google Scholar

Brown, S. and M.K. Yicel, 2002. Energy prices and aggregate economic activity: An interpretive survey. Quarterly Review of Economics and Finance, 42(1): 193-208. View at Google Scholar $\mid$ View at Publisher

Charnes, A., E.L. Frome and P.L. Yu, 1976. The equivalence of generalized least squares and maximum likelihood estimates in the exponential family. Journal of the American Statistical Association, 71 (353): 169-171. View at Google Scholar |View at Publisher

Chen, S.S., 2010. Do higher oil prices push the stock market into bear territory? Energy Economics, 32(2): 490-495. View at Google Scholar $\mid$ View at Publisher

Huang, R.D., R.W. Masulis and H.R. Stoll, 1996. Energy shocks and financial markets. Journal of Futures Markets: Futures, Options, and Other Derivative Products, 16(1): 1-27. View at Google Scholar | View at Publisher

Masih, R., S. Peters and L. De Mello, 2011. Oil price volatility and stock price fluctuations in an emerging market: Evidence from South Korea. Energy Economics, 33(5): 975-986. View at Google Scholar | View at Publisher

\section{Bibliography}

Basher, S.A. and P. Sadorsky, 2006. Oil price risk and emerging stock markets. Global Finance Journal, 17(2): 224-251. View at Google Scholar View at Publisher

Hammoudeh, S.M., Y. Yuan and M. Mc Aleer, 2009. Shock and volatility spillovers among equity sectors of the Gulf Arab stock markets. Quarterly Review of Economics and Finance, 49(3): 829-842. View at Google Scholar | View at Publisher

Marcos, A.D., H. Shankat and G. Rangan, 2013. Detecting predictable non-linear dynamics in Dow Jones industrial average and Dow Jones islamic market indices using nonparametric regressions, Working Papers, No. 201385. 